\title{
Chronic hepatitis B carriers with acute on chronic liver failure show increased HBV surface gene mutations, including immune escape variants
}

\author{
Shan Gao ${ }^{1,2,3}$, Shivali S. Joshi ${ }^{2,3}$, Carla Osiowy ${ }^{4}$, Y. Chen ${ }^{1}$, Carla S. Coffin ${ }^{2,3^{*}}$ and Z-P. Duan ${ }^{1 *}$
}

\begin{abstract}
Background: The pathogenesis of acute-on-chronic liver failure (ACLF) in chronic hepatitis B (CHB) is not well understood. The aim of this study was to investigate whether there is an association between HBV polymerase (P)/ overlapping surface (S) gene and basal core promoter (BCP)/precore $(\mathrm{PC})$ variants and development of ACLF in CHB.

Methods: Two CHB patient cohorts were compared: (i) ACLF (N=12) (11/12 M, median age 52 yrs., 5/9 genotype $C$, 6/12 HBeAg+), (ii) 27 treatment native CHB carriers (15/27 M, median age 44 yrs., 9 genotype B, 10 genotype C, 1 genotype A, 5 genotype D, 2 genotype E). Clonal sequencing of PCR-amplified HBV P/S and BCP/PC gene fragments was done and HBV diversity, frequency of immune escape (IE) and drug resistance (DR) mutations and mutations in BCP/PC gene (G1896A and A1762T/G1764A), were compared between each group.

Results: Our data showed the incidence of IE and clusters of mutations in the HBV S region was significantly greater in ACLF patients vs. treatment naive CHB patients $(p<0.05)$. Additionally, a significantly higher frequency of $\mathrm{G} 1896 \mathrm{~A}$ and A1762T/G1764A mutations were found in HBeAg negative than in ACLF patients $(p<0.0001)$.

Conclusion: In our study, ACLF was not associated with a specific genomic mutation. However, higher frequency of IE mutations along with various mutations clustering in the HBV S region could contribute to or be an outcome of ACLF in CHB infection. (words 226).
\end{abstract}

Keywords: Hepatitis B virus, Mutants, Fulminant liver failure, Viral diversity, Immune escape

\section{Background}

The Hepatitis B virus (HBV) is as a non-cytopathic virus and its induced liver injury in chronic hepatitis B (CHB) carriers is mediated by the host immune response. Acute-on-chronic liver failure (ACLF) is defined as an acute hepatic insult manifesting as jaundice and coagulopathy, complicated within 4 weeks by ascites and/or encephalopathy in a patient with chronic liver disease [1]. Severe HBV flares can lead to ACLF, especially in patients with

\footnotetext{
*Correspondence: cscoffin@ucalgary.ca; duanzp2517@outlook.com

${ }^{2}$ Calgary Liver Unit, Division of Gastroenterology and Hepatology,

Department of Medicine, Cumming School of Medicine, University of Calgary 6D21, Teaching, Research and Wellness Building, 3280 Hospital Drive N.W, Calgary, AB T2N 4Z6, Canada

${ }^{1}$ Artificial Liver Center, Beijing Youan Hospital, Capital Medical University, 8 Xitoutiao, Youwai Street, Beijing 100069, China

Full list of author information is available at the end of the article
}

underlying cirrhosis and manifests as sudden HBV DNA increase followed by biochemical (alanine amino transferase, ALT) increase. Acute exacerbation of CHB can affect $40-50 \% \mathrm{HBeAg}$ positive patients in the immune clearance phase [2]. HBV reactivation is seen in $15-30 \%$ of $\mathrm{HBeAg}$ negative patients, which can also result in liver disease decompensation [3]. ACLF is associated with $>50 \% 3$-month mortality rates without liver transplantation $[4,5]$, yet the pathogenesis is poorly understood.

The development of ACLF is attributed to both host and viral factors. The viral factors include genotypes, HBe antigen ( $\mathrm{HBeAg}$ ) negativity, and mutations in the HBV precore and core promoter region [6]. High replication of certain viral variants have been associated with a more aggressive disease course $[7,8]$. Acute HBV infection with genotype B1 was reported to frequently lead 
to fulminant hepatitis and a higher mortality rate [9], possibly due to the more immunogenic nature of HBV genotype $B$ and resulting immune-mediated damage [10]. The G1896A mutation in the precore region, which posttranscriptionally abrogates HBeAg expression, was associated with fulminant hepatitis B development [11-13]. The A1762T/G1764A dual mutations in core promoter region were also implicated in fulminant hepatitis $[6,14-16]$ due to improved transcription of pregenomic (pg)-RNA and increased viral replication. In addition, mutations such as T1753 V (genotype A, C or G), T1754S (genotype C or G), G1862 T, T1961 V, C1962D (A, G or T), and A2339G were more frequently found in fulminant hepatitis $[15,17,18]$. The presence of various mutations clustering at enhancer $\Pi$ core promoter region was also demonstrated to contribute to the development of fulminant hepatitis [19]. In contrast, other studies found that the presence of precore and core promoter mutations were not associated with a worse prognosis [20] or pathogenesis of fulminant hepatitis $B$ [19]. Additionally, the presence of several naturally occurring $\mathrm{S}$ protein mutations in fulminant hepatitis $\mathrm{B}$ patients was demonstrated to synergistically affect the secretion competence of HBV, leading to ER stress and hepatocyte injury [21].

Host immunologic factors are key to the pathogenesis of ACLF in CHB [22]. Excessive production of antiinflammatory cytokines, such as interleukin (IL)-6, IL-10 and IL-12 and interferon-gamma was reported in ACLF$\mathrm{CHB}$ patients due to reduced monocyte activation.

Both host immune response and antiviral selective pressure can promote the emergence of mutations in $\mathrm{P} / \mathrm{S}$ and $\mathrm{BCP} / \mathrm{PC}$ regions and evolution of HBV quasispecies. On the other hand, the emergence of certain mutations may cause $\mathrm{HBV}$ reactivation and subsequent ACLF development.

Overall there are few studies, and conflicting data on HBV genetic profiles in $\mathrm{P} / \mathrm{S}$ and $\mathrm{BCP} / \mathrm{PC}$ regions in $\mathrm{CHB}-$ ACLF patients compared with non-ACLF CHB patients. The aim of our study is to compare HBV genetic features by clonal sequencing analysis of $\mathrm{HBV} \mathrm{P} / \mathrm{S}$ and $\mathrm{BCP} / \mathrm{PC}$ regions between a cohort of $\mathrm{CHB}$ patients with ACLF compared to non-ACLF/CHB cases to further investigate the role of viral genetic factors in $\mathrm{CHB}$ disease severity.

\section{Methods}

\section{Patients, clinical and laboratory tests}

In total, 12 ACLF in CHB patients (11/12 male, 12 Chinese, median age 52 yr., range 21-64), were either retrospectively (LF \# 1, 2, 3, 4, 5) or prospectively (LF \# 13, 14, 15, $16,17,18,19)$ recruited from Beijing Youan Hospital, Capital Medical University (CMU). All subjects provided written informed consent under an approved Beijing Youan Hospital (Ethics ID LL-2007-002S) institutional ethics board protocol, according to the World Medical
Association Declaration of Helsinki. Moreover, sequence data from a cohort of 27 treatment-naïve $\mathrm{CHB}$ patients in different clinical immune phases (i.e., immune tolerance, immune active, inactive and $\mathrm{HBeAg}$ negative hepatitis phases) was included in the analysis of current study [23, 24].

The clinical and demographic data of all cases collected included age, sex and ethnicity, HBV plasma viral load by clinical PCR assay (i.e., Abbott Molecular $m 2000$ RealTIMe System, Abbott Park, Illinois, USA, lower limit of detection (LLOD) $10 \mathrm{IU} / \mathrm{mL}$ or $\sim 50$ copies $/ \mathrm{mL}$ at Calgary Liver Unit and Roche COBAS Ampliprep/ COBAS Taqman, Pleasanton, CA, USA, lower limit of detection $20 \mathrm{IU} / \mathrm{mL}$ or $\sim 100$ copies $/ \mathrm{mL}$ ), alanine aminotransferase (ALT), quantitative HBsAg level (qHBsAg, Abbott Diagnostics, Abbott Park, Illinois, USA, sensitivity $<=0.05 \mathrm{IU} / \mathrm{mL}$ or Roche Diagnostics/Elesys HBsAg $\Pi$ assays, Mannheim, Germany, sensitivity of $<=0.05 \mathrm{IU} /$ $\mathrm{mL}$ ), $\mathrm{HBeAg}$ and antibody to $\mathrm{HBeAg}$ (anti-HBe) (Abbott Diagnostics, Mississauga, ON, Canada or Roche Diagnostics/Elecsys HBeAg assays, Mannheim, Germany).

HBV genotype was determined by line probe assay (INNO-LiPA, Innogenetics N. V., Ghent, Belgium at Calgary Liver Unit or by PCR fluorescence assay (specific for genotype B and C, Shanghai Fu Xing Chang Zheng, China). The ACLF in CHB subjects were assessed according to the Asian Pacific Association for the Study of Liver Disease for ACLF diagnosis and management [1]. All subjects were initiated on NA therapy with either lamivudine (300 mg/day, $N=2)$ or entecavir $(0.5 \mathrm{mg} /$ day, $N=11)$ after admission to Beijing Youan Hospital.

\section{Biological sample collection, total DNA isolation and detection of $\mathrm{HBV}$ genome in plasma}

In total, about $50 \mathrm{~mL}$ of EDTA whole blood was collected from each patient. Plasma was isolated by centrifugation and stored at $-80{ }^{\circ} \mathrm{C}$. Total DNA was isolated from $500 \mu \mathrm{L}$ plasma by standard phenol-chloroform/ ethanol precipitation. The DNA isolations were carried out in parallel with negative controls that included water or from plasma of a HBsAg-negative healthy individual (designated the mock extraction control).

HBV DNA was detected by nested PCR in plasma using $\mathrm{HBV} \mathrm{P} / \mathrm{S}$ and $\mathrm{BCP} / \mathrm{PC}$ gene specific primers, respectively. The HBV P/S gene was amplified using previously published primer and conditions [23]. The primer sequences for the first-round $\mathrm{HBV} \mathrm{BCP} / \mathrm{PC}$ gene $\mathrm{PCR}$ were direct $\mathrm{BCP} / \mathrm{PC}$ forward (5'-GCATGGAGACCAC CGTGAAC- $\left.3^{\prime}\right)$ and direct $\mathrm{BCP} / \mathrm{PC}$ reverse $\left(5^{\prime}\right.$-ggaaaga agtcagaaggcaa- $\left.3^{\prime}\right)$; and nested $\mathrm{BCP} / \mathrm{PC}$ forward $\left(5^{\prime}\right.$ CATAAGAGGACTCTTGGACT-3') and nested BCP/ PC (5'-GGCAAAAAAGAGAGTAACTC-3') for the second round. The amplification was performed under conditions below: $94{ }^{\circ} \mathrm{C}$ for 40 s, $55{ }^{\circ} \mathrm{C}$ for 30 s, $72{ }^{\circ} \mathrm{C}$ for $50 \mathrm{~s}, 39$ cycles total. All experiments included parallel 
mock nucleic acid isolations and PCR water negative controls. Positive controls included total DNA isolated from liver tissue of a known HBsAg positive individual or inhouse HBV plasmid DNA (HBV genotype A full genome). The PCR products were gel purified (GenElute Gel Extraction kit, Sigma-Aldrich, Oakville, ON, Canada).

\section{Clonal sequence analysis of HBV overlapping polymerase} $(\mathrm{P}) /$ surface $(\mathrm{S})$ region and basal core promoter $(\mathrm{BCP}) /$ precore $(\mathrm{PC})$ regions

HBV $\mathrm{P} / \mathrm{S}$ gene fragment in $7 / 12$ treatment naïve cases (LF \#3, 5, 13, 14, 16, 17 and 19) and BCP/PC gene fragment in $12 / 12$ subjects were cloned using pGEM $-\mathrm{T}$ Easy Vector Systems (Promega, Madison, USA), followed by plasmid isolation (GenElute Plasmid Miniprep Kit, Sigma-Aldrich, Oakville, ON, Canada) according to manufacturer's instructions. A median 17 clones/sample was sequenced bidirectionally with universal primers at $3730 \mathrm{XL}$ sequencing system (Applied Biosystem, Foster City, CA, USA) and sequences were analyzed with Geneious 7.1.9 and MEGA version 6.06. $\mathrm{HBV}$ diversity (distance \pm SEM) of $\mathrm{HBV} \mathrm{P} / \mathrm{S}$ and $\mathrm{BCP} / \mathrm{PC}$ gene sequences of $\mathrm{CHB} / \mathrm{ACLF}$ patients were compared to previously published sequence data from 27 treatment-naïve $\mathrm{CHB}$ patients of different immune phases [23] by sequences alignment and within group diversity analysis. The HBV P/S clonal sequences were aligned using Genbank reference sequences published previously [23], translated for $\mathrm{S}$ and $\mathrm{P}$ protein and aligned with sequences of the same genotype to determine putative nongenotypic substitutions. For all clones, aa $61-250$ of the RT/P and aa $100-200$ of the $\mathrm{S}$ antigenic determinant region were analysed. The G1896A mutation in PC region and A1762T/ G1764A dual mutations in $\mathrm{BCP} / \mathrm{PC}$ region were analysed in $\mathrm{HBV} \mathrm{BCP} / \mathrm{PC}$ clones of different groups.

\section{Data analysis}

An analysis of variability (ANOVA) with appropriate post hoc test was used for the comparison of continuous data and the chi-square or Fisher's exact test was used for the comparison of categorical data. Two-tailed $p$ values of $<0.05$ were considered statistically significant. Statistical analysis was performed with Prism 6.0.

\section{Results}

\section{Demographic, serological, and histological data of CHB} patients

The clinical data of study subjects is summarized in Table 1 . In total, 7 treatment naive CHB, 5 NA-experienced cases with ACLF were enrolled (median age 52 yrs., 11/12 M, 6/ $12 \mathrm{HBeAg}$ positive) (Additional file 1: Table S1). At the time of hospital presentation and sample collection all patients were not on active NA therapy ( 5 cases LF \# 1, 2, 4, 15 and 18 had stopped treatment median 5 months previously). 8/12 patients had underlying cirrhosis according to the results of abdominal ultrasound. The overall median serum HBV viral load of all ACLF patients was $4.7 \mathrm{log}$ IU/ $\mathrm{mL}$ (range 2.2-7.3, data not shown). The median serum $\mathrm{HBV}$ viral load was log $5.7 \mathrm{IU} / \mathrm{mL}$ (range 4.3-7.3) and log $3.7 \mathrm{IU} / \mathrm{mL}$ (range 2.2-5.9) of $\mathrm{HBeAg}$ positive and $\mathrm{HBeAg}$ negative CHB-ACLF patients, respectively. All ACLF cases were found to have $\mathrm{HBV}$ reactivation as the cause of ACLF. Co-infection with hepatitis A, Delta, C and E was excluded. HBV genotype test (done by clinical assay) was available in 8/12 cases and showed that 3 were HBV genotype B vs. 5 genotype C. 4/12 patients died within 4 weeks of presentation, and 8/12 patients who received rescue NA therapy survived at week 4 of follow-up from onset of liver failure, with 5/12 decline in HBV DNA and ALT and improved liver function.

\section{ACLF in CHB patients carry more mutations at residues associated with immune escape (IE)}

In 7/12 NA-treatment naïve ACLF / CHB patients, the HBV P/S gene fragment was amplified by nested PCR (LF \#3, 5, 13, 14, 16, 17 and 19). The incidence of HBV mutations at positions associated with immune escape (IE) and drug resistance (DR) between $\mathrm{CHB}$ patients with ACLF versus treatment naïve $\mathrm{CHB}$ patients of different phases was compared. The incidence of IE mutants was higher in ACLF patients (median 27\%) than in treatment naïve $\mathrm{CHB}$ subjects of different clinical phases (median 6\%-8\%) (Fig. 1a). However, minor HBV DR mutations were found with comparable frequency among all patient groups $(p>0.05$; Fig. 1b). Clusters of mutations between aa 100-200 of S gene were observed in all 7 ACLF in CHB patients (Additional file 1: Table S2-S3, Figure S2).

\section{Higher incidence of A1762T/G1764A and G1896A mutations in $\mathrm{HBV} B C P / P C$ region in $\mathrm{HBeAg}$ negative hepatitis $\mathrm{B}$ patients}

The HBV BCP/PC gene fragment was amplified in $12 /$ 12 ACLF in CHB patients, and mutations therein compared between $\mathrm{HBeAg}$ positive $(N=6)$ and $\mathrm{HBeAg}$ negative $(\mathrm{N}=6)$ groups, respectively. The median frequency of A1762T/G1764A dual mutations in BCP region was significantly higher in $\mathrm{HBeAg}$ negative hepatitis CHB $\left(67 \%,{ }^{* * * * *} p<0.0001\right)$ as well as the immune active CHB group $(6 \%, " p<0.05)$ compared to the ACLF-CHB cohort (both $0 \%$ in both HBeAg positive and HBeAg negative) (Fig. 2a). In addition, the A1762T/G1764A mutations were more frequently seen in immune active $\mathrm{CHB}$ group than in both ACLF-CHB groups $\left({ }^{* * * * * *} p<0.0001\right.$; Fig. 2a). Similarly, the incidence of classic G1896A mutation in $\mathrm{HBV}$ precore region was significantly higher in $\mathrm{HBeAg}$ negative hepatitis group (80\%) than that in both ACLFCHB groups $(0 \%, * * * * 0.0001)$ and immune active group $\left(0 \%,{ }^{* * * * * *} p<0.0001\right.$; Fig. $\left.2 b\right)$. HBV genetic diversity 
Table 1 Demographic and clinical data of Chronic Hepatitis B (CHB)-associated Acute-on-Chronic Liver Failure (ACLF) patients $(N=12)$, treatment naive $\mathrm{CHB}$ patients (NA = 27)

\begin{tabular}{|c|c|c|c|c|c|c|}
\hline & \multirow{2}{*}{$\begin{array}{l}\text { CHB-ACLF } \\
(\text { HBeAg positive, } N=6)\end{array}$} & \multirow{2}{*}{$\begin{array}{l}\text { CHB-ACLF } \\
\text { (HBeAg negative, } N=6)\end{array}$} & \multicolumn{4}{|c|}{ Treatment naïve $\mathrm{CHB}$} \\
\hline & & & $\begin{array}{l}\text { Immune } \\
\text { tolerance }(N=2)\end{array}$ & $\begin{array}{l}\text { Immune active } \\
(N=9)\end{array}$ & Inactive $(N=5)$ & $\begin{array}{l}\text { HBeAg negative } \\
\text { hepatitis }(N=11)\end{array}$ \\
\hline $\begin{array}{l}\text { Median age } \\
\text { (range)/\# male }\end{array}$ & $49(21-64) / 6$ & $52(26-57) / 5$ & $28(20-35) / 1$ & $47(23-50) / 2$ & $52(45-61) / 1$ & $43(36-57) / 11$ \\
\hline Ethnicity & 6 Chinese & 6 Chinese & $\begin{array}{l}1 \text { Chinese; } 1 \\
\text { Eastern European }\end{array}$ & $\begin{array}{l}6 \text { Chinese; } \\
1 \text { Tibetian; } \\
1 \text { Vietnam; } \\
1 \text { Indonesia }\end{array}$ & $\begin{array}{l}3 \text { East- Europe; } 1 \\
\text { Korean; } 1 \text { African }\end{array}$ & $\begin{array}{l}6 \text { Chinese; } 1 \text { Lebanese; } \\
2 \text { Vietnam; } 1 \text { Fillipino; } \\
1 \text { Egyptian }\end{array}$ \\
\hline $\begin{array}{l}\text { Median HBV DNA } \\
\text { (rang, log IU/mL) }\end{array}$ & $5.7(4.3-7.3)$ & $3.7(2.2-5.9)$ & $8.5(8.0-8.6)$ & $8.0(4.5-9.0)$ & 3.1 (UD-3.6) & $4.3(2.9-6.2)$ \\
\hline $\begin{array}{l}\text { Median ALT } \\
\text { (rang, U/L) }\end{array}$ & $562(23-1584)$ & $112(48-2347)$ & $37(20-33)$ & $86(27-353)$ & $25(14-48)$ & $48(20-106)$ \\
\hline $\begin{array}{l}\text { \# HBeAg negative } \\
\text { patients }\end{array}$ & $0 / 6$ & $6 / 6$ & $0 / 2$ & $0 / 9$ & $5 / 5$ & $11 / 11$ \\
\hline Genotype & $1 \mathrm{~B} ; 3 \mathrm{C} ; 2$ unknown & 2 B; 2 C; 2 unknown & $1 \mathrm{~B}, 1 \mathrm{D}$ & $3 \mathrm{~B}, 5 \mathrm{C}, 1 \mathrm{D}$ & $\begin{array}{l}1 \mathrm{~A}, 1 \mathrm{~B}, 1 \mathrm{C}, 1 \mathrm{D}, \\
1 \mathrm{E}\end{array}$ & $4 \mathrm{~B}, 4 \mathrm{C}, 2 \mathrm{D}, 1 \mathrm{E}$ \\
\hline $\begin{array}{l}\text { Median } \mathrm{HBsAg} \\
\left(\text { rang, } \log \mathrm{IU} / \mathrm{mL}^{3}\right)\end{array}$ & unknown & unknown & unknown & $4.0(2-9.8)$ & $3.9(2.7-5.1)$ & $3.5(1.6-9.1)$ \\
\hline \# Liver fibrosis & $3 / 6$ & $5 / 6$ & $0 / 2$ & $3 / 9$ & $0 / 5$ & $5 / 11$ \\
\hline $\begin{array}{l}\text { \# History of NA } \\
\text { treatment }\end{array}$ & 1 LAM & 4 LAM & N/A & NA & N/A & NA \\
\hline $\begin{array}{l}\text { \# Surviral (4 weeks } \\
\text { after onset) }\end{array}$ & $2 / 6$ & $2 / 6$ & All alive & All alive & All alive & All alive \\
\hline
\end{tabular}

UD undetectable

in both $\mathrm{P} / \mathrm{S}$ and $\mathrm{BCP} / \mathrm{PC}$ regions did not demonstrate a significant difference among different groups (Additional file 1: Figure S1a-b).

\section{Discussion}

Acute reactivation of chronic hepatitis $\mathrm{B}$ leading to ACLF is a rare clinical entity frequently leading to a lifethreatening liver disease with poor survival without liver transplant. The genetic characteristics and dynamics of HBV quasispecies may reflect distinct host immune responses, and disease courses. However, there is limited and conflicting data on the role of specific HBV variants in the pathogenesis of HBV-related fulminant liver failure. In the present study, the presence of certain mutations and diversity of $\mathrm{HBV} \mathrm{P} / \mathrm{S}$ and $\mathrm{BCP} / \mathrm{PC}$ gene in plasma of ACLF-CHB patients was compared to sequence data from $\mathrm{CHB}$ patients [23] to determine if there were specific genetic profile (i.e., mutations) associated with disease severity. We found that the ACLF patients enrolled were mainly HBV genotype $C(5 / 8)$ and $6 / 12$ were $\mathrm{HBeAg}$ positive. A distinct $\mathrm{BCP} / \mathrm{PC}$ mutation was not characteristic for $\mathrm{HBV}$ genomes in $\mathrm{CHB}$ patients with ACLF. However, various mutations clustering at aa 100-200 of HBV S gene were more common in ACLF$\mathrm{CHB}$ patients. Moreover, the incidence of $\mathrm{S}$ gene IE associated mutations was significantly higher in ACLF$\mathrm{CHB}$ patients compared to treatment naive non-ACLF
$\mathrm{CHB}$ patient of different immune phases. In a recent study, Salpini et al. reported $75.9 \%$ of HBV reactivated patients having more than one HBsAg mutations and most of them (8/13) were located in the major hydrophilic loop [25], which is similar to what we observed in the ACLF-CHB patients due to HBV reactivation.

The dominance of HBV genotype $\mathrm{C}$ in our ACLF-CHB cohort suggested that genotype $C$ might be associated with increased risk of ACLF development. This data is in agreement with some studies in which genotype $C$ (compared to HBV genotype B), was associated with a higher prevalence of HBeAg, higher HBV DNA levels, more aggressive histological activity, as well as severe acute exacerbation and increased risk of HBV reactivation [26-34]. For instance, a study from Taiwan reported genotype $C$ was significantly more frequent in patients with multiple episodes of acute exacerbation who failed to have $\mathrm{HBeAg}$ seroconversion compared with other patients [27]. Additionally, all of the cross-sectional studies from endemic areas in Asia demonstrate that genotype $\mathrm{C}$ is associated with more advanced liver disease than genotype B [26, 35-38]. However, in other reports either no significant difference between genotype $B$ vs $C$ was found in association with acute $\mathrm{CHB}$ exacerbation $[39,40]$, or severe icteric acute exacerbation was associated with genotype $B$ rather than genotype $C[9,41]$.

The G1896A precore mutation was reported in association with fulminant hepatitis B in patients from Japan 


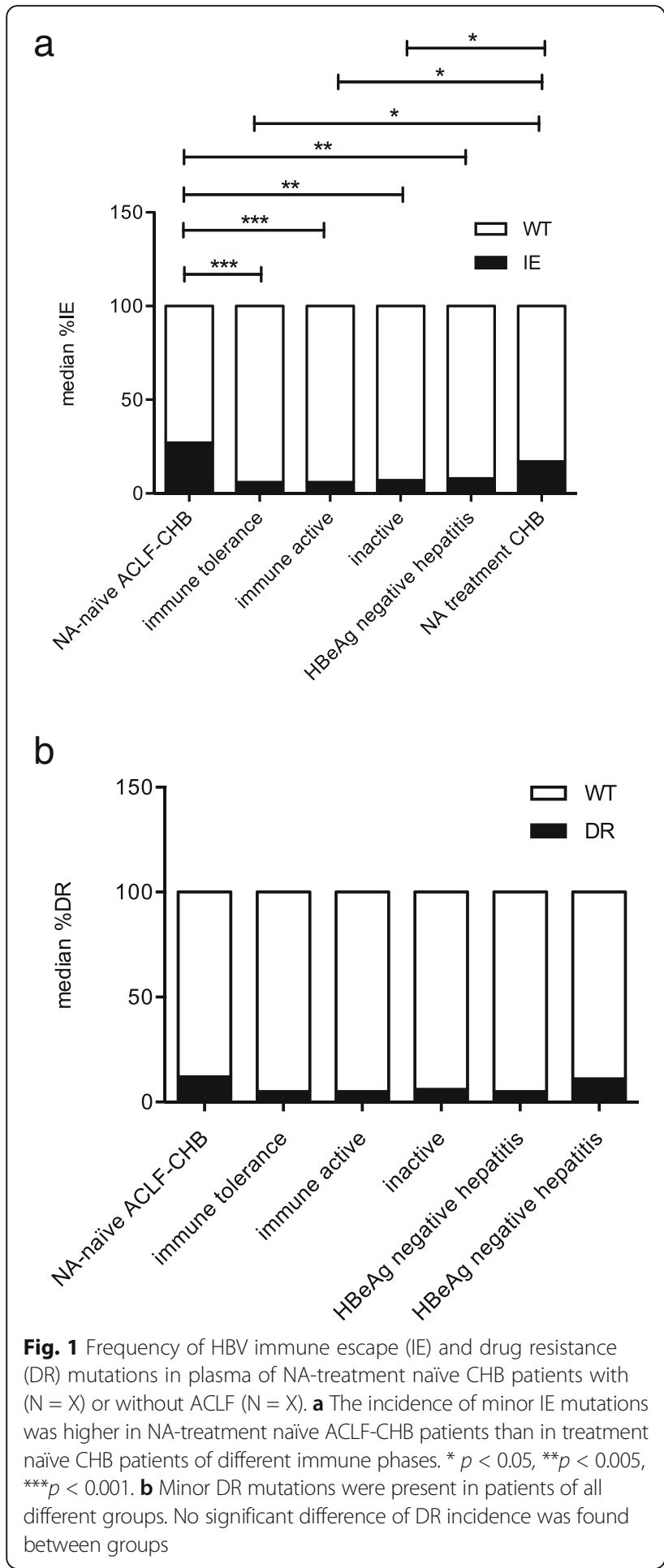

[11, 13, 42-44] Israel [12], and southern Mediterranean countries [45], and the A1762T/G174A mutations in $\mathrm{BCP}$ region was frequently showed in Japanese cohort [16]. However, there have been conflicting reports on the association between specific mutations in the HBV

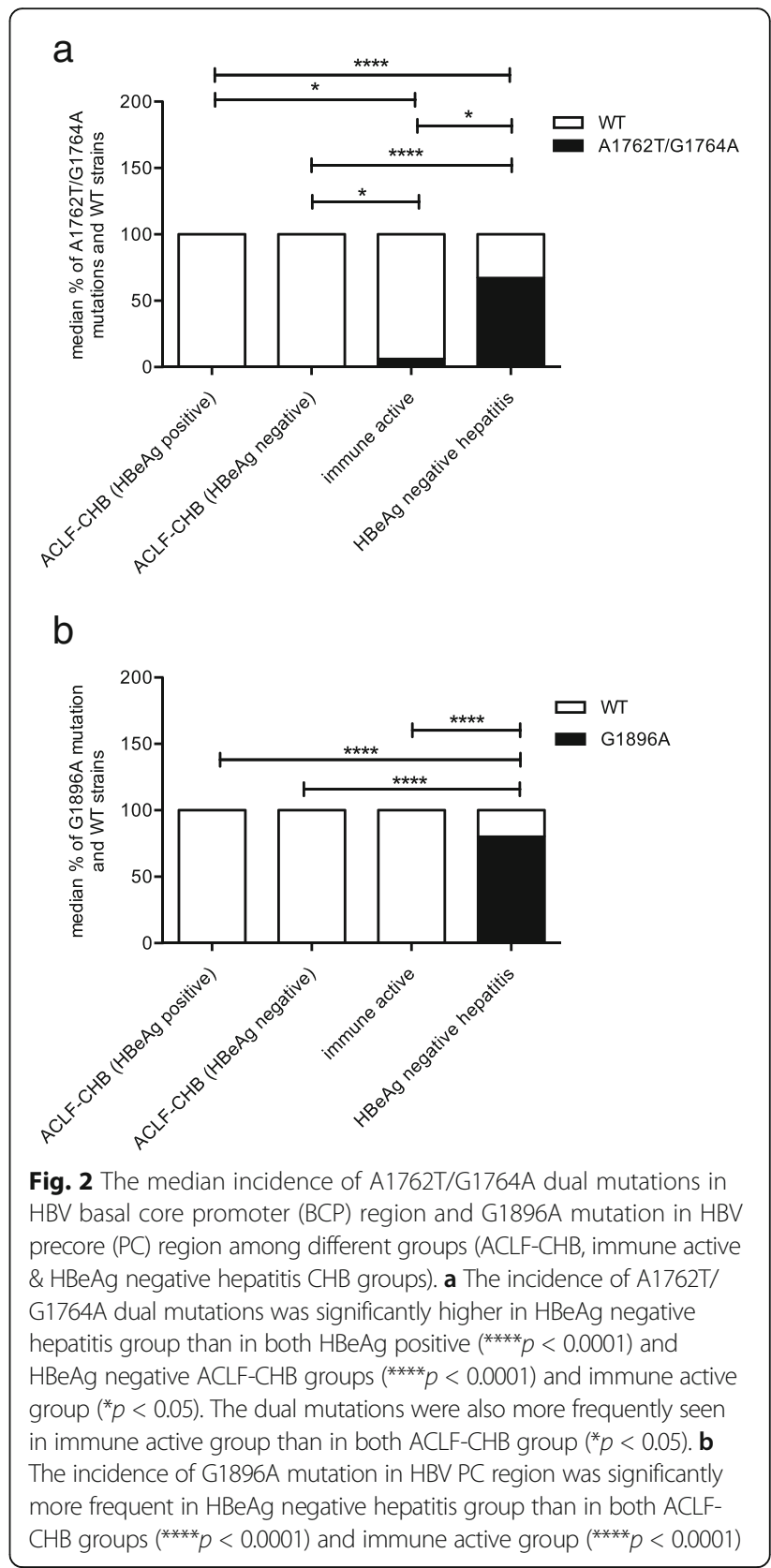

genome and fulminant hepatitis, especially the G1896A and A1762T/G1764A mutations [11, 12, 16, 19, 46]. In our study the frequency of G1896A and A1762T/G1764A mutations was significantly greater in patients from $\mathrm{HBeAg}$ negative hepatitis groups compared to $\mathrm{CHB}$ patients with ACLF. Our data also demonstrated no significant difference of diversity in $\mathrm{HBV} \mathrm{P} / \mathrm{S}$ and $\mathrm{BCP} / \mathrm{PC}$ gene in patients from ACLF-CHB groups compared with other groups.

The emergence of $\mathrm{S}$ viral variants with altered biological function have been implicated in the pathogenesis of ACLF. The variants can be cytotoxic due to enhanced protein expression or lead to altered 
immunogenicity, resulting in immune escape or robust immune response. Specific $S$ gene mutations or a combination of all $\mathrm{S}$ gene mutants were found to be responsible for viral secretion defect or even completely blocked viral particle secretion in in vitro functional studies [21].

Minor drug resistant (DR) mutations in HBV $\mathrm{P}$ gene were found in all patient groups sequenced with no intergroup significant difference noted. Further no detectable NA resistance (i.e., YMDD (tyrosine-methionine-aspartateaspartate) mutation) was noted in any of the ACLF-CHB patient by clinical assay (data not shown). This indicated the emergence of DR mutants and subsequent viral breakthrough was not the cause of ACLF occurrence in our patient cohort (even despite previous exposure to NA therapy). As expected, acute hepatic flare in $8 / 12$ cases with underlying cirrhosis precipitated decompensation. It should be noted that according to APASL the term "acute on chronic liver failure" is used for chronically HBV infected patients regardless of whether they have cirrhosis or not. However, the US Acute Liver Failure study group and the American Association for the Study of Liver Disease differentiates between HBV infected patients that develop ALF (i.e, if cirrhotic designated as HBV-ACLF vs. non-cirrhotic designated as HBV-ALF). However, for the purpose of this study we used the APASL guidelines for the definition of ACLF, for all 12 patients (8/12 cirrhotic) enrolled.

The study was limited by sample size with only $12 \mathrm{pa}-$ tients with ACLF. Further, assessment of HBV in liver tissue, longitudinal follow-up and NGS of HBV full genome sequences could provide greater details on HBV quasispecies. However, ACLF is a rare and devastating clinical entity of which there is limited published systematic analysis of HBV variants.

In summary, the pathogenesis of fulminant hepatitis B has been linked to three main virological markers as (i) an increased viral replication, (ii) a change of viral gene expression and/or (iii) an alteration of $\mathrm{B}$ and $\mathrm{T}$ cell epitopes [47].

\section{Conclusions}

Our study demonstrated greater incidence of IE mutations and clusters of variants in HBV S genes were present in ACLF-CHB patients compared to other non-ACLF CHB patient. Interestingly, the G1896A and A1762T/G1764A mutations, although associated with fulminant hepatitis B development in other studies, were found at low frequency in ACLF patients compared to non-ACLF/HBeAg negative hepatitis $\mathrm{CHB}$ patients. Additional studies including functional assessment of $\mathrm{HBV}$ variants using in vitro models as well as analysis of host factors (i.e., HBV specific immune responses) will help increase our understanding of the mechanisms of development of ACLF in $\mathrm{CHB}$ patients.

\section{Additional file.}

\begin{abstract}
Additional file 1: Table S1. Clinical and virological data of 12 patients with Chronic-Hepatitis B (CHB)-associated Acute-on-Chronic Liver Failure (ACLF). Table S2. The substitutions between aa 100-200 region of HBV S gene in plasma from in Chronic Hepatitis B patients with Acute/Chronic Liver Failure. Table S3. Summary of classic IE mutations and list of classic IE mutations and other mutations in "a determinant" region of HBV S gene found in Chronic Hepatitis B patients with Acute/Chronic Liver Failure $(N=7)$. Figure S1. Comparison of HBV P/S and BCP/PC sequences diversity in $\mathrm{CHB}$ patients with and without Acute-on-Chronic Liver Failure (ACLF). (a) Analysis of HBV P/S sequence diversity in plasma among different groups. The viral diversity of $\mathrm{P} / \mathrm{S}$ sequences was comparable between each group. (b) Analysis of HBV BCP/PC sequence diversity in plasma of different groups. There was no significant difference in HBV diversity of BCP/PC gene observed among distinct groups. Figure S2. Alignment of HBV S gene consensus sequences within the "a" determinant region to HBV sequences from a cohort of chronic HBV patients with Acute/ Chronic Liver Failure $(N=7)$. The classic IE mutations in the patients were indicated by red arrows while other substitutions are noted by black arrows. Both classic IE-associated and other substitutions in "a" determinant are common among these patients. A specific list of substitutions for each patient is provided in Additional file 1: Table S3. (DOCX $588 \mathrm{~kb}$ )
\end{abstract}

\section{Abbreviations}

ACLF: Acute on chronic liver failure; ALT: Alanine transaminase; BCP: Basal core promotor; CHB: Chronic hepatitis B; DR: Drug resistant; HBeAg: Hepatitis B e antigen; HBV: Hepatitits B virus; IE: Immune escape; NA: Nucleot/side analogue; NGS: Next generation sequencing; P: Polymerase; PC: Precore; RT: Reverse transcriptase; S: Surface

\section{Acknowledgements}

The authors thank Yingying Jiang and Wei Lin for collecting the clinical data of ACLF in CHB in Beijing Youan Hospital.

\section{Funding}

This work was supported by the National Science and Technology Key Project on Major Infectious Diseases such as HIV/AIDS, Viral Hepatitis Prevention and Treatment (2017ZX10203201-005, 2017ZX10105005-003-003, 2017ZX10201201, 2017ZX10202203-006-001, 2017ZX10302201-004-002) and Beijing Municipal Administration of Hospitals Ascent Plan (No. DFL20151601). ZP-Duan is the recipient of both grants.

\section{Availability of data and materials}

All data generated or analysed during this study are included in previously published articles (references $[23,24]$ ) and this published article and/or its supplementary information files.

\section{Author's contributions}

SG performed the sample collection, clonal sequencing and analysis, data interpretation, drafted the manuscript. SJ assisted with clonal sequencing. CO assisted with sequencing and data analysis. YC assisted with recruitment of ACLF patients and clinical data collection. CC performed study design and data interpretation, recruited the non-ACLF CHB patients, and was a major contributor in manuscript editing and critical revision of the article. ZP-D recruited all the ACLF patients and performed critical revision of the article. All authors read and approved the final manuscript.

\section{Ethics approval and consent to participate}

All subjects provided written informed consent under an approved Beijing Youan Hospital (Ethics ID LL-2007-002S) institutional ethics board protocol, according to the World Medical Association Declaration of Helsinki.

\section{Consent for publication}

It will be provided as requested.

Competing interests

The authors declare that they have no competing interests. 


\section{Publisher's Note}

Springer Nature remains neutral with regard to jurisdictional claims in published maps and institutional affiliations.

\begin{abstract}
Author details
${ }^{1}$ Artificial Liver Center, Beijing Youan Hospital, Capital Medical University, 8 Xitoutiao, Youwai Street, Beijing 100069, China. ${ }^{2}$ Calgary Liver Unit, Division of Gastroenterology and Hepatology, Department of Medicine, Cumming School of Medicine, University of Calgary 6D21, Teaching, Research and Wellness Building, 3280 Hospital Drive N.W, Calgary, AB T2N 4Z6, Canada. ${ }^{3}$ Department of Microbiology, Immunology and Infectious Diseases, Cumming School of Medicine, University of Calgary, Calgary, AB, Canada. ${ }^{4}$ Bloodborne Pathogens and Hepatitis Laboratory of the National Microbiology Laboratory, Winnipeg, MB, Canada.
\end{abstract}

Received: 14 August 2017 Accepted: 13 October 2017

Published online: 24 October 2017

\section{References}

1. Sarin SK, Kedarisetty CK, Abbas Z, et al. Acute-on-chronic liver failure: consensus recommendations of the Asian Pacific Association for the Study of the liver (APASL) 2014. Hepatol Int. 2014;8(4):453-71.

2. Sheen I-S, Liaw Y-F, Tai D-I, Chu C-M. Hepatic decompensation associated with hepatitis B e antigen clearance in chronic type B hepatitis. Gastroenterology. 1985;89(4):732-5.

3. Lok AS, Lai C-L, P-C W, Leung EK, Lam T-S, Spontaneous h B. E antigen to antibody seroconversion and reversion in Chinese patients with chronic hepatitis B virus infection. Gastroenterology. 1987;92(6):1839-43.

4. Sun QF, Ding JG, DZ X, et al. Prediction of the prognosis of patients with acute-on-chronic hepatitis $B$ liver failure using the model for end-stage liver disease scoring system and a novel logistic regression model. J Viral Hepat. 2009;16(7):464-70.

5. Cui Y-L, Yan F, Wang Y-B, et al. Nucleoside analogue can improve the longterm prognosis of patients with hepatitis $B$ virus infection-associated acute on chronic liver failure. Dig Dis Sci. 2010;55(8):2373-80.

6. Ozasa A, Tanaka Y, Orito E, et al. Influence of genotypes and precore mutations on fulminant or chronic outcome of acute hepatitis $B$ virus infection. Hepatology. 2006;44(2):326-34.

7. Hasegawa K, Huang J, Rogers SA, Blum HE, Liang TJ. Enhanced replication of a hepatitis B virus mutant associated with an epidemic of fulminant hepatitis. J Virol. 1994;68(3):1651-9.

8. Pult I, Chouard T, Wieland S, Klemenz R, Yaniv M, Blum HEA h B. Virus mutant with a new hepatocyte nuclear factor 1 binding site emerging in transplant-transmitted fulminant hepatitis B. Hepatology. 1997;25(6):1507-15.

9. Yuen M-F, Sablon E, Wong DK-H, et al. role of hepatitis B virus genotypes in chronic hepatitis B exacerbation. Clin Infect Dis. 2003:37(4):593-7.

10. Yuen MF, Wong $D$, Zheng BJ, et al. Difference in $T$ helper responses during hepatitis flares in hepatitis B e antigen ( $\mathrm{HBeAg}$ )-positive patients with genotypes B and C: implication for early HBeAg seroconversion. J Viral Hepat. 2007;14(4):269-75.

11. Omata M, Ehata T, Yokosuka O, Hosoda K, Ohto M. Mutations in the precore region of hepatitis $B$ virus DNA in patients with fulminant and severe hepatitis. N Engl J Med. 1991;324(24):1699-704.

12. Liang TJ, Hasegawa K, Rimon N, Wands JR, Ben-Porath EA h B. Virus mutant associated with an epidemic of fulminant hepatitis. N Engl J Med. 1991; 324(24):1705-9.

13. Kosaka Y, Takase K, Kojima M, et al. Fulminant hepatitis B: induction by hepatitis $B$ virus mutants defective in the precore region and incapable of encoding e antigen. Gastroenterology. 1991:100(4):1087-94.

14. Tamada Y, Yatsuhashi H, Masaki N, et al. Hepatitis B virus strains of subgenotype A2 with an identical sequence spreading rapidly from the capital region to all over Japan in patients with acute hepatitis B. Gut. 2012; 61(5):765-73.

15. Kusakabe A, Tanaka Y, Mochida S, et al. Case-control study for the identification of virological factors associated with fulminant hepatitis B. Hepatol Res. 2009; 39(7):648-56.

16. Sato $S$, Suzuki $K$, Akahane $Y$, et al. Hepatitis B virus strains with mutations in the core promoter in patients with fulminant hepatitis. Ann Intern Med. 1995; 122(4):241-8

17. Imamura $T$, Yokosuka $O$, Kurihara $T$, et al. Distribution of hepatitis $B$ viral genotypes and mutations in the core promoter and precore regions in acute forms of liver disease in patients from Chiba, Japan. Gut. 2003;52(11): 1630-7.

18. Inoue J, Ueno Y, Kawamura K, et al. Association between $\mathrm{S} 21$ substitution in the core protein of hepatitis B virus and fulminant hepatitis. J Clin Virol. 2012;55(2):147-52

19. Sterneck M, Gunther S, Santantonio T, et al. Hepatitis B virus genomes of patients with fulminant hepatitis do not share a specific mutation. Hepatology. 1996;24(2):300-6.

20. Chien R-N, Lin C-H, Liaw Y-F. The effect of lamivudine therapy in hepatic decompensation during acute exacerbation of chronic hepatitis B. J Hepatol. 2003;38(3):322-7.

21. Kalinina T, Riu A, Fischer $L$, Will H, Sterneck MA. Dominant hepatitis B virus population defective in virus secretion because of several S-gene mutations from a patient with fulminant hepatitis. Hepatology. 2001;34(2):385-94.

22. Maini MK, Boni $C$, Lee $C K$, et al. The role of virus-specific CD8+ cells in liver damage and viral control during persistent hepatitis B virus infection. J Exp Med. 2000;191(8):1269-80

23. Coffin C, Osiowy C, Gao S, Nishikawa S, Meer F, Marle G, Hepatitis B. Virus (HBV) variants fluctuate in paired plasma and peripheral blood mononuclear cells among patient cohorts during different chronic hepatitis B (CHB) disease phases. J Viral Hepat. 2015;22(4):416-26.

24. Gao S, Duan ZP, Chen Y, et al. Compartmental HBV evolution and replication in liver and extrahepatic sites after nucleos/tide analogue therapy in chronic hepatitis B carriers. Journal of clinical virology : the official publication of the Pan American Society for Clinical Virology. 2017;94:8-14.

25. Salpini R, Colagrossi L, Bellocchi MC, et al. Hepatitis B surface antigen genetic elements critical for immune escape correlate with hepatitis B virus reactivation upon immunosuppression. Hepatology. 2015;61(3):823-33.

26. Kobayashi $M$, Arase $Y$, Ikeda $K$, et al. Clinical characteristics of patients infected with hepatitis B virus genotypes a, B, and C. J Gastroenterol. 2002;37(1):35-9.

27. Kao J-H, Chen P-J, Lai M-Y, Chen D-S. Genotypes and clinical phenotypes of hepatitis B virus in patients with chronic hepatitis B virus infection. J Clin Microbiol. 2002:40(4):1207-9.

28. Lindh M, Hannoun C, Dhillon AP, Norkrans G, Horal P. Core promoter mutations and genotypes in relation to viral replication and liver damage in east Asian hepatitis B virus carriers. J Infect Dis. 1999:179(4):775-82.

29. Kao J-H, Chen P-J, Lai M-Y, Chen D-S, Hepatitis B. Genotypes correlate with clinical outcomes in patients with chronic hepatitis B. Gastroenterology. 2000;118(3):554-9.

30. Orito E, Mizokami M, Sakugawa $H$, et al. A case-control study for clinical and molecular biological differences between hepatitis B viruses of genotypes B and C. Hepatology. 2001;33(1):218-23.

31. Nakayoshi T, Maeshiro T, Nakayoshi T, et al. Difference in prognosis between patients infected with hepatitis B virus with genotype B and those with genotype C in the Okinawa Islands: a prospective study. J Med Virol. 2003;70(3):350-4.

32. Sumi $\mathrm{H}$, Yokosuka $\mathrm{O}$, Seki $\mathrm{N}$, et al. Influence of hepatitis B virus genotypes on the progression of chronic type B liver disease. Hepatology. 2003;37(1):19-26

33. Lee C, Chen C, Lu S, et al. Prevalence and clinical implications of hepatitis B virus genotypes in southern Taiwan. Scand J Gastroenterol. 2003;38(1):95-101.

34. Kao JH, Chen PJ, Lai MY, Chen DS, Hepatitis B. Virus genotypes and spontaneous hepatitis B e antigen seroconversion in Taiwanese hepatitis B carriers. J Med Virol. 2004;72(3):363-9.

35. Lindh M, Horal P, Dhillon AP, Norkrans G, Hepatitis B. Virus DNA levels, precore mutations, genotypes and histological activity in chronic hepatitis B. J Viral Hepat. 2000;7(4):258-67.

36. Sakugawa $H$, Nakasone $H$, Nakayoshi $T$, et al. Preponderance of hepatitis $B$ virus genotype $\mathrm{B}$ contributes to a better prognosis of chronic HBV infection in Okinawa, Japan. J Med Virol. 2002;67(4):484-9.

37. Orito E, Ichida T, Sakugawa $H$, et al. Geographic distribution of hepatitis B virus (HBV) genotype in patients with chronic HBV infection in Japan. Hepatology. 2001;34(3):590-4.

38. Sugauchi F, Chutaputti A, Orito E, et al. Hepatitis B virus genotypes and clinical manifestation among hepatitis B carriers in Thailand. J Gastroenterol Hepatol. 2002;17(6):671-6.

39. Yuen MF, Sablon E, Yuan HJ, et al. Significance of hepatitis B genotype in acute exacerbation, HBeAg seroconversion, cirrhosis-related complications, and hepatocellular carcinoma. Hepatology. 2003:37(3):562-7.

40. Chu CJ, Hussain M, Lok AS, Hepatitis B. Virus genotype B is associated with earlier HBeAg seroconversion compared with hepatitis B virus genotype $C$. Gastroenterology. 2002;122(7):1756-62. 
41. Chan HL-Y, Tsang SW-C, Wong M-L, et al. Genotype B hepatitis B virus is associated with severe icteric flare-up of chronic hepatitis B virus infection in Hong Kong. Am J Gastroenterol. 2002;97(10):2629-33.

42. Yotsumoto S, Kojima M, Shoji I, Yamamoto K, Okamoto H, Mishiro S, Fulminant $h$. Related to transmission of hepatitis $B$ variants with precore mutations between spouses. Hepatology. 1992;16(1):31-5.

43. Hasegawa K, Huang J, Wands JR, Obata H, Liang TJ. Association of hepatitis B viral precore mutations with fulminant hepatitis B in Japan. Virology. 1991;185(1):460-3.

44. Ehata T, Omata M, Chuang W, et al. Mutations in core nucleotide sequence of hepatitis B virus correlate with fulminant and severe hepatitis. J Clin Investig. 1993;91(3):1206.

45. Carman WF, Fagan EA, Hadziyannis $S$, et al. Association of a precore genomic variant of hepatitis B virus with fulminant hepatitis. Hepatology. 1991;14(2):219-22

46. Baumert TF, Rogers SA, Hasegawa K, Liang TJ. Two core promotor mutations identified in a hepatitis B virus strain associated with fulminant hepatitis result in enhanced viral replication. J Clin Investig. 1996;98(10):2268.

47. Sterneck M, Kalinina T, Günther $\mathrm{S}$, et al. Functional analysis of HBV genomes from patients with fulminant hepatitis. Hepatology. 1998;28(5):1390-7.

\section{Submit your next manuscript to BioMed Central} and we will help you at every step:

- We accept pre-submission inquiries

- Our selector tool helps you to find the most relevant journal

- We provide round the clock customer support

- Convenient online submission

- Thorough peer review

- Inclusion in PubMed and all major indexing services

- Maximum visibility for your research

Submit your manuscript at www.biomedcentral.com/submit 